\title{
Helminths of the Ezo Brown Frog, Rana pirica (Ranidae), from Hokkaido Island, Japan ${ }^{1}$
}

\author{
Stephen R. Goldberg ${ }^{2}$ and Charles R. Bursey ${ }^{3}$
}

\begin{abstract}
Rana pirica Matsui, endemic to Hokkaido Island, Japan, was examined for helminths. One species of Monogenea, Polystoma ozakii; three species of Nematoda, Cosmocercoides pulcher, Oswaldocruzia socialis, and Rhabdias nipponica; and one species of Acanthocephala, Acantbocephalus lucidus, were found. Rana pirica represents a new host record and Hokkaido Island a new locality record for $O$. socialis, $R$. nipponica, and $A$. lucidus. None of the helminths found in this study is restricted to Hokkaido Island.
\end{abstract}

The Ezo в rown frog, Rana pirica Matsui, 1991 , is endemic to and the only anuran on Hokkaido Island, Japan, where it lives from plains to montane regions up to $2000 \mathrm{~m}$ (Maeda and Matsui 1999). However, the salamanders Hynobius retardatus Dunn, 1923, and Salamandrella keyserlingii Dybowski, 1870, also occur on Hokkaido Island (Frost 1985). The only previous report of anuran helminths on Hokkaido Island was by Uchida et al. (1988) of the monogenean Polystoma ezoensis Uchida, Machida, Uchida and Itagaki, 1988, from Rana cbensinensis Kawamura, 1962. Rana chensinensis from Hokkaido Island is a synonym of $R$. pirica (see Matsui 1991), and Polystoma ezoensis is a synonym of P. ozakii Price, 1939 (see Goldberg and Bursey 2002). In this article we report additional helminths from $R$. pirica.

\section{MATERIALS AND METHODS}

Eighteen Rana pirica (snout-vent length $=$ $29.7 \mathrm{~mm} \pm 14.1 \mathrm{SD}$, range $=17-53 \mathrm{~mm}$ ) were collected by hand on 4 July 2001 at

${ }^{1}$ Manuscript accepted 24 June 2002.

2 Corresponding author. Department of Biology, Whittier College, Whittier, California 90608 (E-mail: sgoldberg@whittier.edu).

${ }^{3}$ Department of Biology, Pennsylvania State University, Shenango Campus, Sharon, Pennsylvania 16146.

Pacific Science (2003), vol. 57, no. 2:167-169 (C) 2003 by University of Hawai'i Press All rights reserved the Yukomambetsu River, Asahidake Onsen, ca. $1010 \mathrm{~m}$ elevation, Higashikawa-machi, Kamikawa-gun ( $43^{\circ} 38^{\prime} \mathrm{N}, 142^{\circ} 48^{\prime} \mathrm{E}$ ), Hokkaido Prefecture, Hokkaido Island, Japan. Frogs were fixed in 10\% neutral buffered formalin and preserved in $70 \%$ ethanol for a month. In August 2001 they were examined for helminths. The body cavity was opened by a longitudinal incision from throat to vent. The lungs, bladder, and digestive tract were removed, opened longitudinally, and examined under a dissecting scope. The body cavity was also examined. Helminths were removed, placed on a glass slide in a drop of undiluted glycerol, covered with a coverslip, and examined under a compound microscope. Nematodes were identified from the glycerol slides; monogeneans and acanthocephalans were regressively stained in Delafield's hematoxylin, mounted in Canada balsam, and identified. Frogs were deposited in the herpetology collection of the Natural History Museum of Los Angeles County (LACM), Los Angeles, California, as LACM 147874-147891.

\section{RESULTS}

One species of Monogenea, Polystoma ozakii; three species of Nematoda, Cosmocercoides pulcher Wilkie, 1930, Oswaldocruzia socialis Morishita, 1926, and Rbabdias nipponica Yamaguti, 1935; and one species of Acanthocephala, Acantbocepbalus lucidus Van Cleave, 1925 , were found.

Helminths were placed in vials of $70 \%$ ethanol and deposited in the United States National Parasite Collection (USNPC) as Poly- 
TABLE 1

Infection Site, Number of Helminths, Prevalence, Mean Intensity \pm 1 SD, and Range for Helminths from 18 Rana pirica from Hokkaido Island, Japan

\begin{tabular}{|c|c|c|c|c|c|}
\hline Helminth & Infection site & $\begin{array}{l}\text { No. of } \\
\text { Helminths }\end{array}$ & $\begin{array}{l}\text { Prevalence } \\
(\%)\end{array}$ & $\begin{array}{l}\text { Mean Intensity } \\
\quad \pm 1 \mathrm{SD}\end{array}$ & Range \\
\hline \multicolumn{6}{|l|}{ Monogenea } \\
\hline Polystoma ozakii & Urinary bladder & 1 & 6 & 1 & - \\
\hline \multicolumn{6}{|l|}{ Nematoda } \\
\hline Cosmocercoides pulcher & Small, large intestines & 9 & 22 & $2.3+1.9$ & $1-5$ \\
\hline Oswaldocruzia socialis & Stomach, small intestine & 58 & 44 & $7.3 \pm 5.1$ & $1-13$ \\
\hline Rbabdias nipponica & Lung & 48 & 78 & $3.4 \pm 4.1$ & $1-16$ \\
\hline \multicolumn{6}{|l|}{ Acanthocephala } \\
\hline Acantbocepbalus lucidus & Small intestine & 84 & 67 & $7.0 \pm 5.1$ & $1-17$ \\
\hline
\end{tabular}

stoma ozakii, 92107; Cosmocercoides pulcher, 92108; Oswaldocruzia socialis, 92109; Rbabdias nipponica, 92110; Acantbocepbalus lucidus, 92111. Infection site, numbers of helminths, prevalence, mean intensity $\pm 1 \mathrm{SD}$, and range for helminths are given in Table 1.

\section{DISCUSSION}

None of the helminths found in this study is restricted to Hokkaido Island. Polystoma ozakii was originally identified as $P$. intergerrium from Rana ornativentris collected on Honshu Island, Japan (Ozaki 1935) and later described by Price (1939). It has also been reported from Rana japonica (Uchida et al. 1988) collected on Honshu Island. Cosmocercoides pulcher, originally described from Rana japonica collected on Honshu Island, Japan, by Wilkie (1930), is known from anurans from Borneo, Japan, Okinawa, Russia, and Taiwan: Bufo bankorensis, B. bufo, B. gargarizans, B. raddei, Chirixalus eiffingeri, Rana amurensis, Rana bolsti, Rana isbikawae, Rana swinboana, Rana ornativentris, Polypedates leucomystax (Goldberg and Bursey 2002). Oswaldocruzia socialis, originally described from Rana japonica collected on Honshu Island by Morishita (1926), is known from Japanese anurans Bufo japonicus, Rana nigromaculata, $R$. ornativentris, $R$. tagoi, Rbacopborus arboreus, $R$. scblegelii and the lacertid lizard Takydromus tacbydromoides from Honshu Island, Japan (Goldberg and Bursey 2002). Rbabdias nipponica, originally described from Rana rugosa collected on Honshu Island by Yamaguti (1935), is known from anurans from China, Japan, and Vietnam: Buergeria buergeri, Hyla japonica, Rana guentheri, R. japonica, $R$. limnocharis, $R$. nari$n a, R$. nigromaculata, $R$. ornativentris, $R$. tagoi (Goldberg and Bursey 2002). Acanthocephalus lucidus, orginally described from Rana japonica collected on Honshu Island by Van Cleave (1925), has been reported from Japanese anurans Buergeria buergeri, Rana nigromaculata, $R$. ornativentris, $R$. porosa, $R$. rugosa, $R$. tagoi; salamanders Andrias japonicus, Hynobius retardatus; lizard Takydromus tacbydromoides; and snake Elaphe quadrivirgata (Goldberg and Bursey 2002). In view of the distribution patterns of these helminths as well as the close proximity of Hokkaido Island to Honshu Island, Japan, it is not surprising that the same species of helminths occur on both islands.

\section{Literature Cited}

Frost, D. R., ed. 1985. Amphibian species of the world: A taxonomic and geographical reference. Allen Press and Association of Systematics Collections, Lawrence, Kansas.

Goldberg, S. R., and C. R. Bursey. 2002. Helminths of ten species of anurans from Honshu Island, Japan. Comp. Parasitol. 69:162-176.

Maeda, N., and M. Matsui. 1999. Frogs and 
toads of Japan. Rev. ed. Bun-Ichi Sogo Shuppan Co., Tokyo, Japan.

Matsui, M. 1991. Original description of the brown frog from Hokkaido, Japan (genus Rana). Jpn. J. Herpetol. 14:63-78.

Morishita, K. 1926. Studies on some nematode parasites of frogs and toads in Japan, with notes on their distribution and frequency. J. Fac. Sci., Imp. Univ. Tokyo 1:1-32.

Ozaki, Y. 1935. Studies on the frog-trematode Diplorchis ranae. I. Morphology of the adult form with a review of the family Polystomatidae. J. Sci. Hiroshima Univ., Ser. B 3:193-225.

Price, E. W. 1939. North American monogenetic trematodes. IV. The family Poly- stomatidae (Polystomatoidea). Proc. $\mathrm{Hel}-$ minthol. Soc. Wash. 6:80-92.

Uchida, A., M. Machida, K. Uchida, and H. Itagaki. 1988. Studies on the amphibian helminths in Japan (X) two new monogeneans, Polystoma ozakii n. sp. and $P$. ezoensis n. sp., and new locality and host of $P$. racophori. Bull. Azabu Univ. Vet. Med. 9:7-12.

Van Cleave, H. J. 1925. Acanthocephala from Japan. Parasitology 17:149-156.

Wilkie, J. S. 1930. Some parasitic nematodes from Japanese amphibia. Ann. Mag. Nat. Hist. (10th ser.) 6:606-614.

Yamaguti, S. 1935. Studies on the helminth fauna of Japan. Part 10. Amphibian nematodes. Jpn. J. Zool. 6:387-392. 